Agro Ekonomi Vol. 28/No. 2, Desember 2017

\title{
ANALYSIS COMPETITIVENESS OF SUGARCANE FARMING IN CENTRAL JAVA AND EAST JAVA
}

\section{Analisis Daya Saing Usahatani Tebu di Jawa Tengah dan Jawa Timur}

\author{
Wahyu Adhi Saputro ${ }^{1}$, Masyhuri ${ }^{2}$, Any Suryantini ${ }^{3}$ \\ ${ }^{1}$ Master Student of Agricultural Economics, Faculty of Agriculture, UGM \\ ${ }^{2,3}$ Faculty of Agriculture, UGM Jl. Flora No. 1 Bulaksumur, Yogyakarta \\ wahyu.adhi.saputro10@gmail.com
}

Diterima tanggal : 18 Agustus 2017 ; Disetujui tanggal : 17 September 2017

\begin{abstract}
This study aims to determine the competitiveness of sugarcane farming in Central Java and East Java based on comparative advantage (DRCR) and competitive advantage (PCR). The method used was the Policy Analysis Matrix (PAM). The result in Central Java explained that the sugarcane farming do not have comparative advantage but have competitive advantage. It is indicated by the value of Domestic Resource Cost Ratio DRCR $>1$ which is 1.23 and the value of Private Cost Ratio PCR $<1$ which is 0.71 . Meanwhile The result in East Java explained that the sugarcane farming do not have comparative advantage but have competitive advantage. It is indicated by the value of $\mathrm{DRCR}>1$ which is 1.05 and the value of $\mathrm{PCR}<1$ which is 0.56 . Partial test was conducted to find out how many respondents in each region in Central Java and East Java that have competitiveness sugarcane farming. Based on the partial test of each respondent in Central Java, about $51.67 \%, 45.00 \%$ and $3.33 \%$ of respondents are categorized as very competitive, medium competitiveness and very low competitive respectively. Meanwhile, in East Java Province, there are $25.00 \%$ of respondents with very high competitiveness, $65.00 \%$ medium competitiveness and $10.00 \%$ very low competitive.
\end{abstract}

Keywords : Competitiveness, PAM, Sugarcane

\section{INTISARI}

Penelitian ini bertujuan untuk mengetahui daya saing usahatani tebu di Jawa Tengah dan Jawa Timur berdasarkan keunggulan komparatif(DRCR) dan keunggulan kompetitif (PCR). Metode yang digunakan yaitu menggunakan Policy Analysis Matrix (PAM). Hasilnya di Jawa Tengah menjelaskan bahwa usahatani tebu tidak memiliki keunggulan komparatif namun memiliki keunggulan kompetitif. Hal ini ditunjukkan dengan nilai Rasio Biaya Sumber Daya Domestik DRCR> 1 yaitu 1,23 dan nilai Private Cost Ratio $P C R<1$ yaitu 0,71. Sedangkan hasil di Jawa Timur menjelaskan bahwa usahatani tebu tidak memiliki keunggulan komparatif namun memiliki keunggulan kompetitif. Hal ini ditunjukkan dengan nilai DRCR $>1$ yaitu 1,05 dan nilai $P C R<1$ yaitu 0,56. Uji parsial dilakukan untuk mengetahui seberapa banyak jumlah responden pada masing-masing wilayah di Jawa Tengah dan Jawa Timur yang memiliki daya saing usahatani tebu. Berdasarkan uji parsial tiap responden di Jawa Tengah terdapat 51,67\% responden berdaya saing sangat tinggi, 45,00\% berdaya saing sedang dan 3,33\% berdaya saing 
sangat rendah. Sementara itu di Provinsi Jawa Timur terdapat 25,00\% responden berdaya saing sangat tinggi, 65,00\% berdaya saing sedang dan 10,00\% berdaya saing sangat rendah.

Kata Kunci : Daya Saing, Gula, PAM

\section{INTRODUCTION}

One of the commodities that has been developed since the past in Indonesia is sugar cane commodity. The business of sugar cane was developed by of Dutch East India government during the oppression era. At that time, the local sugar cane farm could produce 3 millions of sugar. Sugar cane is a very important commodity in Indonesia. The increasing rate of sugar consumption due to the increasing number of population and the development of industries that use sugar as their main raw material have made sugar cane as the essential commodity. The International Sugar Organization (ISO) stated that the Indonesian sugar consumption will grow $4 \%$ every year. ISO is predicting that in 2012-2013, the import of raw crystal sugar of Indonesia will continue to increase even surpassing China which would make Indonesia as the first importer of Sugar all over the world (Kurniasari, et al, 2015).

One of the main causes of Indonesia to import sugar is the incapability of local sugar industries in fulfilling the increasing needs and demands from the community for sugar. The decreasing productivity of sugar in Indonesia is proved by the decreasing amount of sugar production produced by farmers and the sugar factories. The indecent management of national sugar factories are causing Indonesia to be incapable in fulfilling the sugar demand thus the annual import is required (Prabowo, 2013).

Even since the rule of Dutch East India Government, the sugar cane has been seen as the commercial and potential commodity and being developed continuously by the Indonesian Government through the state-owned and the private sector farm companies. The sugar cane farming is also conducted by the local farmer through the government policy regarding the Intensification of Community Sugar Cane by the rotational planting area system. The productivity of community sugar cane farm which extends to $56 \%$ of sugar cane farms in Indonesia still considered low. Fitriani (2013) mentioned that the potential production of sugar cane farm in Indonesia could reach 8 tons per ha, while the BPS data shows the productivity of Indonesia Sugar Cane in 2013 was only 5.8 tons per ha.

The sugar cane has a very important role in moving the economic condition of one particular area. This role related to its position as the main raw material 
of sugar industry. Sugar is a strategic commodity protected by the government, thus the interventions from them are heavily conducted towards sugar industry. As the manifestation of government concern towards sugar industry, several policies have been issued through price policy, which regulating sugar provenue as the price acceptable either by farmer or sugar industry as the producent. If reviewed from the perspective of sugar cane production in Indonesia, there are three regions that have a massive contribution to sugar cane production including Sumatra, Java, and Sulawesi. Aside from that, it can be also discovered that $64.24 \%$ of sugar raw material production in Indonesia comes from Java Island. While Sumatra has $34.41 \%$ percentage and Sulawesi has $2.34 \%$. In that order, the biggest supplier of sugar in Indonesia is located in Java Island. Java Island has the highest production compared to other islands. In Java Island, there are four provinces that have the highest sugar cane production including East Java in the top rank, followed by Central Java, West Java, and Yogyakarta Special Province. East Java Province has $75.73 \%$ of percentage in producing sugar cane, while Central Java has $17.73 \%$. These two provinces are the regions that own massive contribution in supplying the sugar cane in Java Island. This condition has become the basis of this research to study the sugar cane competitiveness in
Java Island especially in Central Java and East Java Province, thus Indonesia would be no longer depended on sugar import.

One of the reasons of low competitiveness of sugar commodity is the incapability of national sugar industry in fulfilling the national sugar demand, thus the sugar import is relatively high (Susilowati and Rahman, 2016). The high rate of sugar import in Indonesia resulted in decreasing price of sugar, therefore the farmer's motivation to conduct sugar cane agricultural farming also decreased. In that order, the development of several determining factors of this commodity has to be monitored.

Indonesia has been recorded in the sixth place of the biggest sugar importer in 1981. However, the current sugar production has decreased this record. In 1990 , Indonesia is no longer included in the 10 biggest sugar importers (PSE, 1996). During the 1984-1986 period, the world sugar trading marked by the overproduction which resulted in the decreasing price towards its lowest level. However, since 1989, this condition has turned into over demand that causing the depletion of stock and the rocketing value in the world market. World Bank has predicted that the world sugar price will continue increasing until the year of 2007 , with the average price of US $\$ 0.13$ per pound or 12 percent more than the price in 1992 (World Bank, 1993). 
The high price of sugar in the domestic market is a reflection of low competitiveness in the market. Government policy in the field of production, processing that leads to intervention to the problem. Meanwhile, subsidies are only aimed at suppressing higher prices and world market prices. The market's actors that favor the subvention are sugar factory, BULOG and traders. On the other hand (the customer) has to bear the loss due purchasing sugar with a higher price. For the sugar cane's farmer, although they also favor the subvention in the form of provenue price and production facility price, they are still at disadvantages due to the inability to produce other commodities.

Due to the emergence of that problem, then the analysis towards sugar cane business competitiveness need to be conducted as the consideration in selecting the policy to improve the competitiveness of sugar cane's farmer. This research aimed to discover the comparativeness and competitiveness of sugar cane farming in East Java and Central Java.

\section{METHODS}

\section{Location and Data}

The selection of the research location was purposive because geographically the land structure in Kediri was a good sugar cane plantation that has a high sugarcane rendering while for the location of Central Java was chosen in Karanganyar this was due to have in place have a sugar factory with the largest milling capacity and one of the cane centers. The survey was conducted at government-owned sugar cane plantations, where the selected recipes were built from the Tasikmadu sugar factory in Karanganyar and Pesantren Baru sugar factory in Kediri. Types of data collected in this study were primary and secondary data and data were collected from September to December 2016. Primary data were obtained from interviews with farmers who run sugar cane farming, as respondents using a structured questionnaire. The number of respondents used in each district 60 cane farmers. The sample selection method was simple random sampling. Sugarcane farmers who become respondents are farmers who are milled sugar cane, so that more understand the inputs used to produce the output.

\section{Analysis Method}

This research is analyzed using PAM (Policy Analysis Matrix) method. Stages in the preparation of PAM tables are as follows (Monke and Pearson in Setiawan et al, 2014):

1. Identify all inputs used in the production process

2. Allocate tradable input and non tradable input.

3. Calculating the price of shadow input, output, and exchange rate.

4. Analyze comparative and competitive advantages and policy impacts with the PAM model. 
Table 1. Input Output Cost Allocation in Domestic and Foreign Components

\begin{tabular}{|c|c|c|}
\hline Component & Domestic $(\%)$ & Foreign $(\%)$ \\
\hline Sugar & 0.00 & 100.00 \\
\hline $\mathrm{ZA}$ & 0.00 & 100.00 \\
\hline Phonska & 0.00 & 100.00 \\
\hline Transport & 44.86 & 55.14 \\
\hline Labor & 100.00 & 0.00 \\
\hline Land Rent & 100.00 & 0.00 \\
\hline Rent a Tractor & 33.00 & 67.00 \\
\hline Capital Interst & 100.00 & 0.00 \\
\hline Depreciation Equipment & 100.00 & 0.00 \\
\hline
\end{tabular}

Source: Table Input Output Indonesia, 1995 (processed) in Saptana, 2002

Table 2. Policy Analysis Matrix (PAM)

\begin{tabular}{lcccc}
\hline & \multirow{2}{*}{ Revenue } & \multicolumn{2}{c}{ Cost } & \multirow{2}{*}{ Profit } \\
\cline { 3 - 4 } & & Tradable input & Non tradable input & \\
\hline Private Cost & $\mathrm{A}$ & $\mathrm{B}$ & $\mathrm{C}$ & $\mathrm{D}=\mathrm{A}-\mathrm{B}-\mathrm{C}$ \\
Social Cost & $\mathrm{E}$ & $\mathrm{F}$ & $\mathrm{G}$ & $\mathrm{H}=\mathrm{E}-\mathrm{F}-\mathrm{G}$ \\
Impact Policy & $\mathrm{I}=\mathrm{A}-\mathrm{E}$ & $\mathrm{J}=\mathrm{B}-\mathrm{F}$ & $\mathrm{K}=\mathrm{C}-\mathrm{G}$ & $\mathrm{L}=\mathrm{I}-\mathrm{J}-\mathrm{K}$ \\
\hline
\end{tabular}

Source: Pearson et al (2004)

PAM is composed of a matrix constructed by inputting components of acceptance, cost, and profit. The PAM analysis results inform the competitive and comparative advantage as well as the impact of government policies on particular commodity systems. Model of PAM matrix can be seen in table 2 .

Where :

The acceptance of sugar cane farming at private prices $=\mathrm{A}$

Total cost tradable sugarcane farming at private price $=\mathrm{B}$

Total cost of non tradable sugarcane farming at private price $=\mathrm{C}$

Private profit $=\mathrm{D}$
The acceptance of sugar cane farming at social prices $=\mathrm{E}$

Total cost tradable sugarcane farming at social price $=\mathrm{F}$

Total cost of non tradable sugarcane farming at social price $=\mathrm{G}$

Social profit $=\mathrm{H}$

Transfer output $(\mathrm{OT})=\mathrm{I}$

Transfer input $(\mathrm{IT})=\mathrm{J}$

Transfer Factor $(\mathrm{TF})=\mathrm{K}$

Transfer bersih $(\mathrm{NT})=\mathrm{L}$

Private Cost Ratio $(\mathrm{PCR})=\mathrm{C} /(\mathrm{A}-\mathrm{B})$

Domestic Resources Cost Ratio (DRCR)

$=\mathrm{G} /(\mathrm{E}-\mathrm{F})$

Nominal Protection Coefficient Output $(\mathrm{NPCO})=\mathrm{A} / \mathrm{E}$

Nominal Protection Coefficient Input 
$(\mathrm{NPCI})=\mathrm{B} / \mathrm{F}$

Effective Protection Coefficient $(\mathrm{EPC})=$ (A-B)/(E-F)

Profitability Coefficient $(\mathrm{PC})=\mathrm{D} / \mathrm{H}$

Subsidy Ratio to Producers $(\mathrm{SRP})=\mathrm{L} / \mathrm{E}$

The first line is a calculation based on the private price of the actual price actually received by the farmer, including the government's policy. The second line is a calculation based on the social price of the price received economically without any government policy in it. The social price is derived from the international price already converted to the shadow exchange rate.

The determination of the Rupiah exchange rate is based on the development of the foreign currency exchange rate of US Dollar in 2016. Gittinger (1986 in Marjaya et al, 2013) based on Squire Van de Tak formulated a formula for determining the currency exchange rate shadow value: Standard conversion factors. The standard conversion factor value which is the ratio of the import and export value plus the tax can be determined as follows.

$$
\begin{gathered}
S C F=\frac{M+X}{(M+T m t)+(X-T x t)}, \\
S E R t=\frac{\text { OERt }}{S C F t}
\end{gathered}
$$

Where :

SCFt : Standard Conversion Factor for year-t
$\mathrm{Xt}$ : Export Value of Indonesia for year-t $(\mathrm{Rp})$

Mt : Indonesian Import Value for year-t (Rp)

Txt : Government Revenue from Export Tax for year-t (Rp)

Tmt : Government Revenue from Import Tax for year-t (Rp)

SERt : Shadow exchange rate (Rp)

OERt : Official exchange rate $(\mathrm{Rp})$

$\mathrm{SCFt}$ : Standart conversion factor $(\mathrm{Rp})$

\section{RESULTS AND DISCUSSION}

\section{Policy Analysis Matrix (PAM)}

PAM is used to analyze the economic condition of sugar cane farming business from the perspective of private benefit as well as giving a measurement of economic efficiency level or social benefit. According to Monke and Pearson (2005), the PAM Model provides complete and consistent understanding towards the entire policy influence and the market fail on the revenue, cost, and profit in the agricultural production sector widely. From the analysis result of the competitiveness of sugar cane agricultural business in Bantul Regency, the private and social prices are presented in the form of PAM table. PAM table can be used to determine the competitive and comparative advantages by measuring the value of PP, SP, PCR, and DCR according to the PAM table. Table 3 shows the private and imaginary prices from the output and 
Table 3. Policy Analysis Matrix (PAM)

\begin{tabular}{lrrrr}
\hline \multirow{2}{*}{ Description } & \multirow{2}{*}{ Revenue } & \multicolumn{2}{c}{ Cost } & \multirow{2}{*}{ Profit } \\
\cline { 3 - 4 } & & Tradable Input & $\begin{array}{c}\text { Non Tradable } \\
\text { Input }\end{array}$ & \\
\hline Central Java & & & & \\
Privat & $39,978,900$ & $4,042,547$ & $25,654,382$ & $13,279,971$ \\
Social & $25,584,586$ & $5,199,779$ & $25,228,764$ & $-4,843,957$ \\
Impact Policy & $14,394,314$ & $-1,157,232$ & 425,618 & $15,125,928$ \\
\hline East Java & & & & \\
Privat & $57,294,500$ & $6,291,429$ & $28,605,811$ & $25,816,760$ \\
Social & $35,739,547$ & $8,429,841$ & $28,717,383$ & $-934,939$ \\
Impact Policy & $21,554,953$ & $-2,138,412$ & $-111,572$ & $26,751,699$ \\
\hline
\end{tabular}

Source: Primary Data Analysis, 2017

input components of sugar cane agricultural business of Central Java and East Java Province in 2016.

According to the Table 3, the private and social revenues in Central Java Province are IDR 39,978,000 and IDR $25,584,586$ respectively, while the private and social revenues in East Java Province are IDR 57,294,500 and IDR 35,739,547 respectively. Private revenues in East Java are greater when compared to private revenues in Central Java due to the result of sugar cane output in East Java greater than in Central Java so that the effect on revenues will be greater in East Java

Reviewed from these numbers, the private revenues are bigger compared to the social revenues. The difference in these revenues resulted from the market divergence. Market divergence causing the difference value between private and social prices, in this context is the output that earned by the sectors. The existing market divergence is causing the revenue deficit about IDR 14,394,314 for Central Java Province and IDR 21,554,953 for East Java Province. Market divergence can possibly occur due to the government policy that is protective towards the output price.

The tradable input cost in private price is lower compared to the tradable input cost in social price. The non-tradable input cost in private price is also lower compared to the non-tradable input cost in social price. The difference of tradable input value in private price with the tradable input value in social price is IDR 1,156,232 for Central Java and - IDR 2,138,412 for East Java Province. The difference of non-tradable input value in private price with the non-tradable input value in social price is - IDR 111,572 for East Java Province. This condition shows the existence of subvention caused by the government policy that applied in the market of tradable and nontradable input. This subvention is naturally profiting the farmer, or on the other words, the 
government policy is on the farmer side. In the column of cost for Central Java Province, if the cost value of tradable and non-tradable inputs are summarized thus the cost value of input in private price will be larger than the cost input in social price. The total cost amount in private and social prices are IDR 26,698,929 and IDR $30,428,543$ or IDR 731,614 in difference. This number shows that the input price in the international market is higher compared to the domestic prize as well as the inefficient input utilization. Aside from that, the allocation of input cost from the domestic sector is larger than the input allocation from the international sector. Therefore, the transformation in social price only has a small influence towards the total cost of social input. By discovering the difference of price between the domestic and the international, the competitiveness of sugar cane agricultural business in Central Java and East Java Provinces could be found. The sugar cane agricultural business in Central Java and East Java Province is financially profitable, however, it's economically disadvantaging. This can be seen from the profit column.
The financial profit or the profit of sugar cane agricultural business of private sector in Central Java and East Java Province is positive, while for the economic or social profit is negative. The difference between financial and economic profit also valued positively. The government policy is causing the profit transfer from the consumer towards the producent.

\section{Analysis of Comparative Advantage of Sugar Cane Farming in Central Java and East Java Provinces}

The comparative advantage is the ability of a particular region to produce a commodity with decent quality and efficient cost. The comparative advantage can be discovered from the social profitability (SP) exist in the PAM matrix on the second line of profit column. Aside from that, domestic resource cost ratio (DRCR) is also used. The indicators of social profit and the domestic resource cost ratio are the indicators acquired from the calculation by using social price or the price that applied in the international market.

The social profit of sugar cane agricultural business in Central Java and

Table 4. Indicator of Comparative Advantage of Sugarcane Farming Central Java and East Java Provinces

\begin{tabular}{lrr}
\hline \multicolumn{1}{c}{ Description } & \multicolumn{2}{c}{ Value } \\
\cline { 2 - 3 } & \multicolumn{1}{c}{ Central Java } & \multicolumn{1}{c}{ East Java } \\
\hline Social Profit (Rp) & $-4,843,953.00$ & $-1,407,677.00$ \\
Domestic Resources Cost Ratio (DRCR) & 1.23 & 1.05 \\
\hline
\end{tabular}

Souce: Primary Data Analysis, 2017 
East Java according to the Table 4 is negative about IDR 4,843,953 and IDR $1,407,477$. This shows that there is a subsidy used by farmers in East Java especially for fertilizers, besides that sugarcane farmers in East Java are more efficient to use the inputs that are compared to inputs used by sugar cane farmers in Central Java. This value acquired from the difference of revenues in social price subtracted with the tradable and non-tradable price in social price as well. The value of social profit of sugar cane agricultural business in Central Java and East Java is negative. In that order, it can be defined that the sugar cane agricultural business in Central Java and East Java Province is not economically profitable.

The domestic resource cost ratio (DRCR) is acquired from the ratio calculation between non-tradable input cost in social price and the difference of revenue and tradable input cost in social price. According to the analysis in the PAM Matrix, the DRCR value of sugar cane agricultural business in Central Java Province is 1.23 and for the East Java Province is 1.05 ; it means that to gain one unit output of social price, 1.03 unit of domestic price need to be sacrificed. The 1.23 and 1.05 value of DRCR (DRCR $>1)$ shows that the sugar cane agricultural businesses in Central Java and East Java Province are not economically efficient. The sugar cane's farmers in Central Java and East Java Province are unable to pay the domestic factor input. The DRCR values of sugar cane agricultural business in Central Java and East Java Province are more than one which means that the sugar cane agricultural business does not have comparative advantages. This condition shows that exporting sugar from agricultural business in Central Java and East Java Province is not profitable.

This condition also stated in several past researches; Ogbe, et al (2011) was researching the competitiveness of Nigerian rice and the ecology of corn production by using Policy Analysis Matrix (PAM). The production of rice and corn in the entire plants' ecology as what shown have negative private profit in the rice farming and the ecology of corn irrigation that shows the lack of competitiveness in farmer's level. In the research of Ariani, et al (2006) regarding the competitive analysis of sugar cane agriculture business in East Java Province, it was acquired that the sugar cane agriculture business in East Java Province is financially profitable. However, in economic side, the losses experienced by the farmer in Madiun and Kediri Region are IDR 2 million - IDR 4 Million per Ha. This difference caused by the market distortion resulted from the government policy. The sugar cane agriculture businesses in Madiun and Kediri Regency have no competitive advantages, while the sugar cane agriculture businesses in Malang 
and Jember Regency show the opposite $(\mathrm{DRCR}<1)$. The sugar cane agriculture businesses in Madiun, Kediri, and Malang Regency (agriculture farm) will have the comparative advantages if the productivity of sugar cane is improved by $20 \%$ or the global price of sugar is 220 USS per ton. The sugar cane agriculture businesses in the entire location could pay the scarification of efficient domestic price $(\mathrm{PCR}<1)$. The input policy regulated by the government has induced an incentive towards sugar cane's farmer in the form of half prices of input price paid by them. Aside from that, the sugar selling price relished by the farmer is higher, around $30-45 \%$ of the actual sugar selling price.

The research conducted by Saptana, et al (2002) regarding the efficiency and the competitiveness of sugar cane and tobacco agriculture businesses in East Java and Central Java show that the sugar cane agriculture businesses in Kediri, Ngawi, and Klaten Regency do not have the comparative advantages with $\mathrm{DRC}>1$ coefficient, however they still have the competitive advantages showed by $\mathrm{PCR}<1$ coefficient. However the competitive own by sugar cane farmer is tend to have resulted from the protective policy. The implication is when the sugar cane plant to be developed continuously then the invocation in producing primary good variety, the balance of fertilizer utilization, the improvement of efficiency in the processing industry through the management of brand standardization, the efficiency improvement in distribution through the reduction of any distortion existed as well as through the conducive government's policy.

\section{Analysis of Competitive Advantage of Sugar Cane Farming in Central Java and East Java Provinces}

The competitive advantage is a measurement for competitiveness in the actual economic condition, where the analysis is conducted to measure the financial feasibility. The competitive advantage of a commodity can be seen in accordance with the indicators of Private Profit and Private Cost Ratio. The private profit is calculated based on the price from the accumulation of domestic price factor and the addition output value from the input price that applied in the market (private price) and the private cost ratio (PCR). These indicators show the level of profit financially and the level of efficiency for the utilization of input resources that trading at the private price. Table 5 The Indicators of Competitive Advantage of Sugar Cane Agriculture Business in Central Java and East Java Province.

The private profit is acquired from the difference of IDR 39,978,900 revenue with the tradable input cost about IDR $4,042,547$ and the domestic input or 
Table 5. Indicator of Competitive Advantage of Sugarcane Farming in Central Java and East Java Provinces

\begin{tabular}{lrr}
\hline \multirow{2}{*}{ Description } & \multicolumn{2}{c}{ Value } \\
\cline { 2 - 3 } & Central Java & \multicolumn{1}{c}{ East Java } \\
\hline Private Profit (Rp) & $10,281,971.00$ & $22,397,260.00$ \\
Private Cost Ratio (PCR) & 0.71 & 0.56 \\
\hline
\end{tabular}

Source: Primary Data Analysis, 2017

non-tradable cost about IDR 25,645,382 thus the private profit is acquired about IDR 10,281,971,00 for Central Java Province. The private profit of East Java Province is better which acquired IDR $57,294,500$ from the revenue difference with the tradable input cost about IDR $6,291,429$ and the domestic input or nontradable cost about IDR $28,605,811$ thus the private profit is acquired about IDR $22,387,260$. The value of positive private profit $(\mathrm{PP}>0)$ shows that financially the sugar cane agriculture businesses in Central Java and East Java Province are profitable. Therefore, those sugar cane agriculture businesses are decent to be afforded.

The analysis result acquired from the Table 5.10 shows the PCR value for sugar cane agriculture businesses in Central Java and East Java Province are 0.71 and 0.56 which less than one $(\mathrm{PCR}<1)$, it shows that the sugar cane agriculture businesses are financially efficient which the farmer can afford the domestic input factor or it can be said that the sugar cane agriculture businesses have competitive advantages. The PCR value is closer to the value of 0 or the smaller the value of PCR will actually raise its competitive competitivenessThe 0.71 PCR value also means that to produce one addition of output value in private price, the 0.71 value of domestic input cost has to be sacrificed. Similar to the 0.56 PCR value in East Java Province that means to produce one addition of output unit, 0.44 values can be saved. The smaller PCR value resulted in higher competitive advantage own by that certain commodity. PCR values in East Java are better due to outcomes between the output generated with the input used is more efficient when compared with central Java

This result also in accordance with the research of Soetrion regarding the competitiveness of soybean commodity in the central production of Banyuwangi that mentioned the actual BSD value is smaller than the official exchange value or the competitive advantage will be acquired of the actual KBSD value is $<1$. The entire businesses conducted by the soybean's farmer and the producent of tempe and tofu have a smaller value than its official exchange value with the actual KBSD value is $<1$, it means that the agro-industry 
commodities of soybean; tempe and tofu in

Banyuwangi Regency have the competitive advantages for business.

The PCR analysis towards sugar cane agriculture business above resulted in $\mathrm{PCR}<1$, thus the sugar cane agriculture business in Central Java has competitiveness in financial value but not having the competitiveness in economic value (international) or having the competitiveness but not comparativeness because DRCR $>1$. The government policy is required to improve the sugar social price. This policy can be embodied as the pricing policy. Pricing policy could increase the selling price of imported sugar that could increase the comparative advantage. Aside from that, it has to be known that the PCR value of sugar cane agriculture business has lower value compared to its DCR value or PCR < DCR. This condition reveals that without government policy, in order to produce one additional value, the larger domestic factor compared to the existence of a policy is required. On the other words, the government policy is still required to support the competitiveness in economic value (international).

Partial Test of Sugarcane Farm Competitiveness of each respondent in Central Java and East Java Provinces

The assessments of competitiveness for each respondent of sugar cane agriculture business in Central Java and East Java Province are indeed required. Partial test of each respondent will be divided into three categories of competitiveness is very high, medium, and very low. This assessment is related to the capability of producent to sell and stock the goods or service provided in the market. Aside from that, in order to discover if each respondent has competitiveness, the assessment towards competitive and comparative advantage needs to be conducted. The assessment of the competitiveness of sugar cane agriculture business for each respondent in Central Java and East Java can be seen in Table 6 below.

Table 6. Criteria Assessment of Competitiveness of Each Respondent ini Central Java and East Java Province in 2016

\begin{tabular}{lrr}
\hline \multirow{2}{*}{ Criteria Assesment of Competitiveness } & \multicolumn{2}{c}{ Persentage (\%) } \\
\cline { 2 - 3 } & Central Java & East Java \\
\hline Very High & 51.67 & 25.00 \\
Medium & 45.00 & 65.00 \\
Very Low & 3.33 & 10.00 \\
\hline Total & 100.00 & 100.00 \\
\hline
\end{tabular}

Source: Primary Data Analysis, 2017 
According to Table 6 regarding the assessment of the competitiveness of each respondent for sugar cane agriculture business; it can be known that 31 people (51.67\%) in Central Java and 15 people $(25 \%)$ in East Java have the high criteria of competitiveness. It means that they already conceive the advantages either in competitive or comparative. Aside from that, 27 people $(45 \%)$ in Central Java and 39 people (65\%) in East Java have decent competitiveness; it means that those respondents already have competitiveness but not comparativeness. The existence of sugar cane farmers whose competitiveness is very high and low. This is because there are some sugarcane farmers who are still new and can be categorized as sugarcane farmers who are intensive cultivation by Sinder (cane foreman), while the high competitiveness is usually independent sugarcane farmers.

In that case, the medium/decent criteria still possible to be developed with a note that the government policy that could increase the sugar social price exists, this policy can be embodied as pricing policy. The pricing policy will increase the selling price of imported sugar that could increase the comparative advantage. While there are still two respondent (3.33\%) in Central Java and six people (10\%) that conceive neither comparativeness nor competitiveness which do not need to be developed.

\section{CONCLUSION AND SUGGESTION}

The sugar cane agriculture businesses in Central Java and East Java Province have competitiveness according to the competitive advantage but conceive no comparative advantage. The protection towards the output and input of sugar cane agriculture business in Central Java and East Java due to the policy applied by the government, thus the sugar cane farmer receive output price that higher than its social price and the tradable input price that lower than the social price. The output and input protections applied are one of the efforts implemented by the government to increase the production.

The sugar cane agriculture businesses in Central Java and East Java Province actually decent to be developed because of their medium competitiveness level for national marketing, however not feasible to be traded globally. The production enhancement also required to be conducted by developing the innovation instrument and expeditious technology, for example exchanging the old machines of sugar cane grinding and the development of sugar cane variety that has high immersion thus it can be expected to increase the comparativeness and the competitiveness. The government policy that could increase the sugar social value is also required. This policy can be embodied as the pricing policy. Pricing policy could increase the selling price of imported sugar that could increase the comparative advantage. 
Increased competitive advantage of each sugar cane farmer, especially in East Java, which most of the farmers are still in the category of moderate competitiveness, namely by improving the technical system of sugar cane cultivation where farmers often maintain the production of sugar cane in the fourth ratoon and after. In addition, government policy applies price and output price protection. The use of non-tradable inputs should be more efficient so that it will lower costs.

\section{REFERENCES}

Ariani, M., Askin, A, dan Hestina, J. 2006. Analisis daya saing usahatani tebu di Propinsi Jawa Timur. Jurnal Sosial Ekonomi Pertanian dan Agribisnis Hal: 1-19.

Fitriani., Sutarni., dan Irawati,L. 2013. Faktor-Faktor yang Mempengaruhi Produksi, Curahan Kerja dan Konsumsi Petani Tebu Rakyat di Propinsi Lampung. Jurnal Ilmiah ESAI Volume 7 No.1 Hal : 1.

Gittinger, J. P. 1986. Analisa Ekonomi Proyek-proyek Pertanian Edisi II. Universitas Indonesia Press, Jakarta. Kurniasari, R. I., D. H. Darwanto, dan S. Widodo. 2015. Permintaan gula kristal mentah Indonesia. Jurnal Ilmu Pertanian. Vol 18 : 24 - 30 .
Marjaya, Hartono S, Masyhuri, Darwanto DH. 2013. Analisis Daya Saing Komoditas pada Sistem Usahatani Integrasi Jagung-sapi di Kabupaten Kupang. Jurnal Agribisnis 2: 15-29.

Ogbe, A, O., Okurawa, V, O., and Saka, O.J. 2011. Competitiveness of Nigerian Rice and Maize Production Ecologies :A Policy Analysis Approach, Tropical and Subtropical Agroecosystem Journal, (14): 493-500

Pearson, S.R., Gotsch, C., dan Bahri, S. 2004. Aplikasi Policy Analysis Matrix Pada Pertanian Indonesia. Yayasan Obor Indonesia, Jakarta.

Prabowo, A. S. 2013. Analisis faktorfaktor yang mempengaruhi produksi gula di Jawa Tengah 2004 - 2013. Economics Development Analysis Journal (3): 420 - 426.

Saptana, Supena, dan Bastuti,T. P. 2002. Efisiensi dan Daya Saing Usahatani Tebu dan Tembakau di Jawa Timur dan Jawa Tengah. Pusat penelitian dan Pengembangan sosial Ekonomi Pertanian.

Setiawan, K., Hartono, S., dan Suryantini, A. 2014.Analisis Daya Saing Komoditas Kelapa di Kabupaten Kupang. Jurnal Agritech Vol. 34 No. 1 Hal: 88-9. 
Soetrion. 2004. Analisis Daya Saing Komoditas Kedelai di Sentra Produksi Guna Menunjang Pengembangan Agroindustri. Jurnal Agroekonomi $11(2): 82-91$
Susilowati, S.H dan Tinaprilla, N. 2012. Analisis efisiensi usahatanu tebu di Jawa Timur. Jurnal Littri (18): $162-172$. 